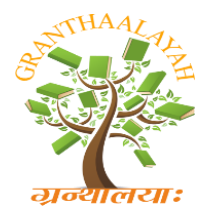

INTERNATIONAL JOURNAL OF RESEARCH GRANTHAALAYAH

A knowledge Repository

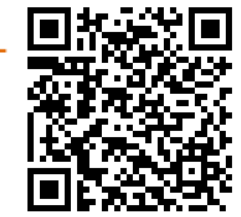

Management

\title{
A PROPOSED MODEL OF THE MEDIATING EFFECT OF STRATEGIC MANAGEMENT ACCOUNTING ON THE RELATIONSHIP BETWEEN PERCEIVED ENVIRONMENTAL UNCERTAINTY AND FIRM PERFORMANCE
}

\author{
Somayeh Soheilirad ${ }^{1}$, Saudah Sofian ${ }^{* 2}$ \\ ${ }^{1}$ Ph.D. Candidate, Faculty of Management, University Teknologi Malaysia, Skudai, 81310, \\ Johor Bahru, MALAYSIA \\ *2 Associate Professor, Faculty of Management, University Teknologi Malaysia, Skudai, 81310, \\ Johor Bahru, MALAYSIA
}

\begin{abstract}
This paper investigates the relationship between contingency factors, strategic management accounting and firm performance. Due to the development and expansion of organizations and their connections to the industrial competition, it is usable that the organization rely more on non-financial information than financial. The management accounting and financial accounting literature have highlighted the important role of perceived environmental uncertainty and strategic management accounting on firm performance. However, unpredictable conditions from external can cause big problems for the company's decision making process because both of them have effect on firm performance. The aim of this paper is to propose a model of the relationship amid perceived environmental uncertainty on the firm performance by mediating effect of strategic management accounting through review of the related literature. One of the most significant findings to emerge from this review is the identification the contingency factors that improve organizational performance under environmental uncertainty.
\end{abstract}

Keywords:

Perceived Environmental Uncertainty, Strategic Management Accounting, Firm Performance.

Cite This Article: Somayeh Soheilirad, and Saudah Sofian, "A PROPOSED MODEL OF THE MEDIATING EFFECT OF STRATEGIC MANAGEMENT ACCOUNTING ON THE RELATIONSHIP BETWEEN PERCEIVED ENVIRONMENTAL UNCERTAINTY AND FIRM PERFORMANCE" International Journal of Research - Granthaalayah, Vol. 4, No. 1 (2016): 231-239.

\section{INTRODUCTION}

Business environment is becoming increasingly complex making it difficult for firms to stay competitive (Haron et al., 2013). In this competitive environment, contingency factors are fast 
becoming a key instrument in business success. Recently management accounting research focuses on the contingency variable to help managers to make effective decisions because these variables have a significant influence on management accounting system and decision making process (Gordon and Narayanan, 1984; Gul and Chia, 1994; Chapman, 1997; Gerdin and Greve, 2004). The assumption of the contingency theory in management accounting is based on the belief that it is necessary to identify the relationship between contingency factors from external organization's environment, on the bases of accounting designs, approaches and techniques. Furthermore, the accounting information is beneficial for companies operating in competitive with long-term strategic tactics (Ismail and King, 2005). In this uncertain environment, the global economy is becoming increasingly uncertain, with rapid technological advances, constantly changing customer demands, increased deregulation and the dismantling of trade barriers (Mia and Clarke, 1999; Schulz, et al., 2010), these uncertain factors can significantly influence firm's chances of survival and success (Kaplan and Norton, 2001; Chenhall, 2003, Govindarajan, 1994).

Therefore, this study proposes the conceptual framework to examine the effect of perceived environmental uncertainty and firm performance by mediating effect of strategic management accounting. The next sections of this paper include a review of the related literature on perceived environmental uncertainty, and firm performance. At the end, developed hypotheses, conceptual framework and conclusion presented.

\section{PERCEIVED ENVIRONMENTAL UNCERTAINTY AND STRATEGIC MANAGEMENT ACCOUNTING}

There is a growing body of literature that recognises the importance of perceived environmental uncertainty. PEU is related to managers' perceived failure to correctly forecast their external environment (Tymon et al., 1998). It has been argued that it is the perceptions of the external environment that administrators respond to, rather than the real physical external environment (Magnusson, 1981; Ferris, 1977). It is obvious that in management accounting research, PEU has appeared as a critical factor in contingency theories (Chenhall, 2003; Fisher, 1992; Otley and Wilkinson, 1998; Tymon et al., 1998).

There is a large volume of published studies describing the relationship between PEU and MAPs. For instance, Gordon and Miller (1976) and Khandwalla (1972) demonstrated that corporations demand more sophisticated accounting information systems to offer more nonfinancial and external information under a high environment uncertainty. Recent developments in PEU have heightened the need for information that is related to the external environment, also needed is future orientated and non-financial to cope with the complexities of their external environment McManus (2012). Moreover, there is an important evidence of budgets becoming more significant under conditions of uncertainty to provide decision making, direction and control. Some authors (Marginson and Ogden, 2005) have proven that administrator's appreciate budgeting in a PEU context as it proposes some structure and stability, a fixed reference in an instant changing environment. Furthermore, Schoute (2009) argued that PEU seems to be significant because a higher level of PEU increases companies' need for information, comprising cost information particularly advanced costing system. 
On the basis of the previous argument and lack of study on perceived environmental uncertainty and strategic management accounting, the following hypothesis is proposed:

H1: There will be a relationship between a perceived environmental uncertainty and strategic management accounting.

\section{STRATEGIC MANAGEMENT ACCOUNTING AND FIRM PERFORMANCE}

Several studies have documented that the major function of an information system is to support managerial decision making and control (Gelinas, et al., 1999; Abernethy and Bouwens, 2005). Previously published studies based on contingency theories indicated that companies' performance will have increased when they used the practices most matched to their features (Chenhall, 2003; Khandwalla, 1972). There is a large volume of published studies which support a positive relation between the usage of MAPs and performance. For instance, Shields (1995) indicated a positive relation between the execution of $\mathrm{ABC}$ and the company financial advantage. Chenhall and Langfield - Smith(1998) found a higher usage of activity-based management, quality improvement programs and benchmarking, yields higher performance for companies.

In another major investigation into commenting on strategic management accounting and performance, kennedy and Affleck-Graves, (2001) and Ittner et al.(2002) conclude that wide $\mathrm{ABC}$ usage is indirectly linked to manufacturing cost decreases within cycle time and quality enhancements and is linked to greater quality levels and higher developments in cycle quality and time. On the other hand, Cagwin and Bouwman (2002) and Maiga and Jacobs (2006) demonstrated that $\mathrm{ABC}$ is associated with ROI and profitability.

The relationship between budgeting practice and performance has a long history in the administrative accounting literature (Frucot and Shearon, 1991). Merchant (1981) aimed to find an association between the usage of budgeting and performance. The results showed that the formal method to budgeting was more intensely linked to better performance in large companies. Furthermore, data from several sources have identified the increasing financial performance are associated with planning and the use of appropriate budgets (Hansen et al., 2003; Perren and Grant, 2000).

So far, however, there has been little discussion about the relationship between SMA techniques usage and performance. Chenhall and Langfield-Smith (1998) found significant relations between SMA techniques and business performances. Cadez and Guilding (2008) revealed a weak relation between the adoption of SMA practices and performance. Recent evidence suggests that there is a medium level relation between SMA adoption and the performance, Sener and Dirlik (2012). Whereas acknowledging these researches' mixed results, there appears to be majority of results indicating a positive association between usage of advanced MAPs and performance.

H2: There will be a relationship between strategic management accounting and firm performance. 


\section{THE INFLUENCE OF PERCEIVED ENVIRONMENTAL UNCERTAINTY ON FIRM PERFORMANCE}

Evidence from practice indicates that firm frequently alter their performance measurement systems in order to accommodate effectively to dynamic circumstances and changing corporate strategies. In the new global economy, environmental uncertainty has become a central issue for every organization because every organization works within an environment (Azadehdel et al.,2012). Companies, in business and industrial markets, face strong competition in rapidly changing environments (Gosselin and Bauwen, 2006). Rumelt (1991) and Wagner et al. (2002) reported that uncertainty is an important aspect of environment because it has a potentially large impact on organisational performance. In an analysis of environmental uncertainty, Regan (2012) suggested that organisational management should be cautious about environmental uncertainty because this is one of the fundamental challenges in organizations. Similarly, Hoque et al., (2001) noted that when organizations are facing higher competition situation, the utilization of different performance measures is expected.

Survey such as that conducted by Jusoh (2008) have noted that manufacturing firms are considered highly competitive and vulnerable to environmental changes. A critical analysis of Daft (2004) demonstrated that each organization's environment is composed of many different factors which have an interaction with the organization strategy decision making. Therefore need more attention from decision units.

Up to now, previous studies have confirmed the effectiveness of environmental uncertainty and organizational performance. Burns and Stalker (1960), Lawrence and Lorsch (1967), Miller (1993) observed external environment as an important element of organization and also their study had empirical support for the significance of environmental factors in determining an organizational performance. Likewise, Isabela and Waddock (1994) noted that there is a positive relationship between business success and the environmental impact and Mia and Clarke (1999) suggested that firm performance can be improved by increasing competition. This is because there is a positive correlation between market competition and performance. In another previous study, Wagner et al., (2002) and Child (1972) also believed that the creating and fostering of a company's capability to forecast and the perceived environmental uncertainty are important for a successful business process.

In another study, Kotha and Nair (1995) concluded that the firm's environment and firm's strategies play important roles on growth and they are significantly related to firm profitability. While, according to Duncan (1972), these environmental factors may only be relevant to manufacturing firms because they are in more competitive environment.

This relation between perceived environmental uncertainty and firm performance is important because the global economy is becoming increasingly uncertain, with constantly changing customer demands, rapid technological advances, increased deregulation and the dismantling of trade barriers Mia and Clarke (1999), Leifer et al., (2001), Puranam et al., (2006). A firm's management accounting related practices can significantly affect its chances of survival and success in this turbulent environment as per Chenhall (2003), Van der Stede et al., (2006), Langfield-Smith (2007), and as such improved understanding of how such practices affect firm 
performance is important to management effectiveness. This inference is consistent with early work by Khandwalla (1972), who documented an increase of performance measurement sophistication in response to increased PEU. For this reason researchers have focused on the environmental aspects of the organization's competitive context.

On the basis of the previous argument and lack of study on perceived environmental uncertainty and firm performance, the following hypothesis is proposed:

H3: There will be a relationship between a perceived environmental uncertainty and firm performance.

H4: there will be the mediating role of Strategic management accounting on the relationship between perceived environmental uncertainty and Firm performance.

\section{CONCEPTUAL FRAMEWORK AND HYPOTHESIS DEVELOPMENT}

To elaborate the pivotal role of contingency factors in recent century this paper proposes a framework that suggests the relationship between perceived environmental uncertainty, and firm performance by considering mediating effect of strategic management accounting.

The independent variable is perceived environmental uncertainty, dependent variable is firm performance, and strategic management accounting consider as mediator. The theoretical framework for this research as presented in Exhibit 1 depicts the relationship between PEU, SMA and firm performance. Proposed Framework and model are as below:

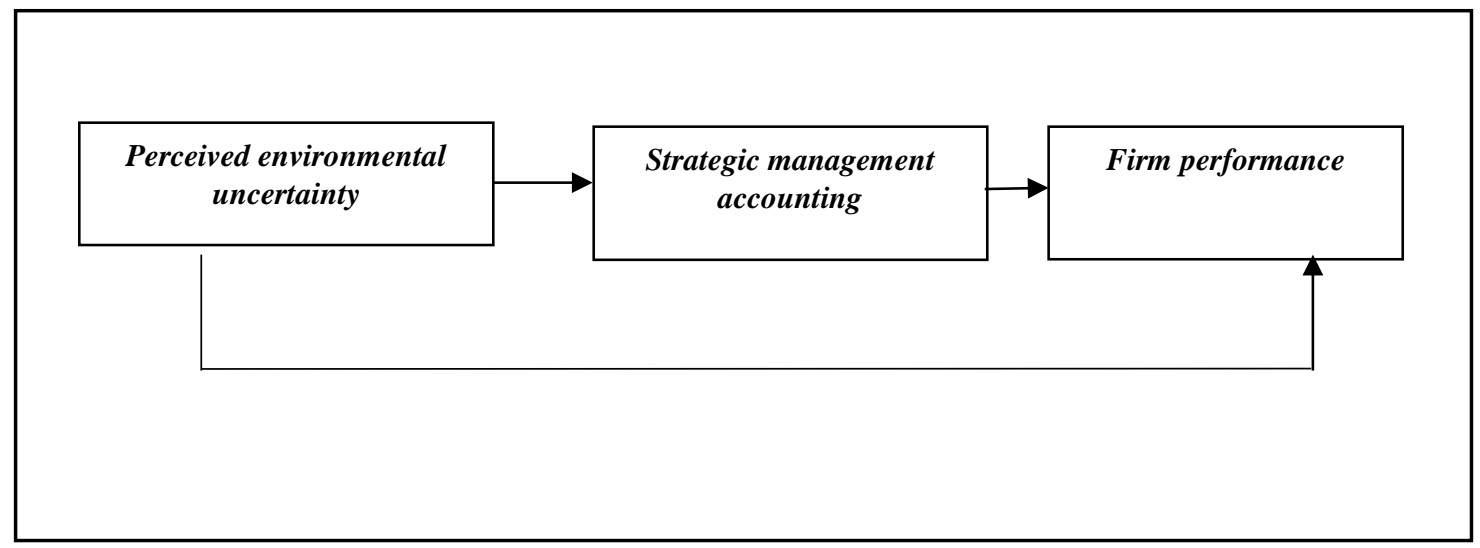

Figure 1: The relationship between perceived environmental uncertainty and Firm performance by mediating effect of Strategic management Accounting-A Conceptual Framework

This study adopted firm performance measurement by applying the questionnaire from Jusoh (2008). Survey items to measure perceived environmental uncertainty was adapted from the empirical studies of Houqe (2005) to measure strategic management accounting, survey items were developed by Cadez and Guilding, (2008); Fullerton et al., (2013); Guilding and McManus (2002). Finally, in this study using PLS-SEM for analysing data.

\section{CONCLUSION AND RECOMMENDATION}

The study contributes to the body of knowledge in several ways. In addition, researchers such as Reed and DeFillippi (1990), Ittner and Larcker (1997), Elbanna and Alhwarai (2012), Watson et 
al. (2004), Wagner (2005) and Link and Naveh (2006) have reported that environmental uncertainty has an influence on firm performance and is a driver for sustainable competitive advantage. In conclusion, managers operating in uncertain environments that adopt a decentralization structure are required to be alert for any changes in its environment as this will have strong impact on business operation. Under such conditions the manager will be requiring a performance measurement system that provides detailed measures of every aspect of business operation. Therefore it is expected that manager with considering and recognizing contingency factors can making good strategic accounting system and therefore try to improve firm performance.

\section{REFERENCES}

[1] Abernethy, M.A. and Bouwens, J. (2005), "Determinants of accounting innovation implementation”, Abacus, Vol. 41, pp. 217-239.

[2] Azadehdel, M., Farahbod, F. and Rahimi, M. (2012). The Modifying Role of Knowledge Management in Relationship among Environment and Organizational Structure Journal of Basic and Applied Scientific Research, 2(3)2758-2764.

[3] Burns, T., and G. Stalker, 1961, The Management of Innovation (Travistock: London, $U K)$.

[4] Cagwin. D and Bouwman. M. J. (2002). "The association between activity-based costing and improvement in financial performance," Management and Accounting Research, Vol. 13, pp. 1-39.

[5] Cadez, S. \& Guilding, C. (2008). "An exploratory investigation of an integrated contingency model of strategic management accounting." Accounting, Organizations and Society. 33(7-8), 836-863.

[6] Chapman, C. (1997). Reflections on a Contingent View of Accounting. Accounting, Organizations and Society, 22 (2), pp. 189-205.

[7] Chenhall, R.H. and Langfield-Smith, K. (1998), "The relationship between strategic priorities, management techniques and management accounting: an empirical investigation using a systems approach”, Accounting, Organizations and Society, Vol. 23, pp. 243-264.

[8] Chenhall, R. H. (2003). "Management Control Systems Design Within its Organizational Context: Findings from Contingency-based Research and Directions for the Future." Accounting, Organizations and Society 28(2/3), 127-168.

[9] Child, J. (1972). "Organizational structure, environment and performance: the role of strategic choice." Sociology 6: 1-22.

[10] Daft, R. L. (2004). Organisational theory and design. 8th edition. Thompson South Western.

[11] Dess, G. G. and D. W. Beard (1984). "Dimensions of Organizational Task Environments" Administrative Science Quarterly, Vol. 29, No. 1be consistent in format of referencing (Mar., 1984), pp. 52-73

[12] Duncan, R. (1972). "Characteristics of organizational environments and perceived environmental uncertainty." Administrative Science Quarterly 17(3): 313-327.

[13] Elbanna, S. and M. Alhwarai (2012). "The Influence of Environmental Uncertainty and Hostility on Organization Performance" UAEU-FBE-Working Paper Series ISSN 20797141.

[14] Ferris, K.R. 1977, 'Perceived uncertainty and job satisfaction in the accounting environment', Accounting, Organizations and Society, Vol. 2, No. 1, pp. 23-28. 
[15] Fisher, J., 1992, "Use of Nonfinancial Performance Measures", Journal of Cost Management 6(1), 31-38.

[16] Frucot, V., and W. T. Shearon. 1991. Budgetary participation, locus of control, and Mexican managerial performance and job satisfaction. The Accounting Review 66 (January): 80-98.

[17] Gelinas, J. J., Sutton, S. G. \& Oram, A. E. (1999). Accounting Information Systems. (4th Ed.). Cincinati, Ohio: South-Western College Publishing, pp. 1-17.

[18] Gerdin, J., and J. Greve, 2004, "Forms of Contingency Fit in Management Accounting Research -- A Critical Review”, Accounting, Organizations and Society 29(3/4), 303-326.

[19] Gordon, L., \& Miller, D. (1976). A contingency framework for the design of accounting information systems. Accounting Organization \& Society, 1(1), 59-69.

[20] Gordon, L.A., and V.K. Narayanan, 1984, "Management Accounting Systems, Perceived Environmental Uncertainty and Organizational Structure: An Empirical Investigation”, Accounting, Organizations and Society 9(1), 33-47.

[21] Gul, F.A., and Y.M. Chia, 1994, "The Effects of Management Accounting Systems, Perceived Environmental Uncertainty and Decentralization on Management Performance: A Test of Three Way Interaction”, Accounting, Organizations and Society 19(4/5), 413-426.

[22] Gosselin, D. P. and G. A. Bauwen (2006). "Strategic account management: customer value creation through customer alignment." Journal of Business \& Industrial Marketing 21/6 (2006) 376-385.

[23] Hansen, S.C., Otley, D.T. and van der Stede, W.A. (2003), "Practice Developments in Budgeting: An Overview and Research Perspective", Journal of Management Accounting Research, Vol. 15, pp. 95-116.

[24] Hoque, Z. (2005). Linking environmental uncertainty to non-financial performance measures and performance: a research note. The British Accounting Review ,37, 471481.

[25] Hoque, Z., Mia, L. and Alam, M. (2001). Market Competition, Computer-Aided Manufacturing And Use Of Multiple Performance Measures: An Emprical Study. British Accounting Review 33, 23-45.

[26] Isabella, L. A., \& Waddock, S. A. 1994. Top management team certainty: Environmental assesments, teamwork, and performance implications. Journal of Management, 20(4): 835-858.

[27] Ismail, N.A. and King, M. (2005). Firm Performance and AIS Alignment in Malaysian SMEs, International Journal of Accounting Information Systems, 6(4), p. 241-259.

[28] Ittner, C. D. and D. F. Larcker (1997). "Quality strategy, strategic control systems, and organizational performance." Accounting, Organizations and Society, 22(3-4), 293-314.

[29] Ittner, C. D. and D. F. Larcker (2002). "The association between activity-based costing and manufacturing performance," Journal of Accounting Research, Vol. 40 (3), June, pp. 711-726.

[30] Jurczak, J. (2008). IC measurement methods. Economics and Organization of Future Enterprise, Vol. 1, issue 1, p. 37-45.

[31] Jusoh, R. (2008). Environmental Uncertainty, Performance, and the Mediating Role of Balanced Scorecard Measures Use: Evidence from Malaysia. International Review of Business Research Papers, 4(2) 116-135 
[32] Kaplan, R. S. and D. P. Norton (2001). "Transforming the balanced scorecard from performance measurement to strategic management: part 1." Accounting Horizon 15 (1), 87 -

[33] Kennedy, Tom and John Affleck-Graves (2001). “The impact of activity-based costing techniques on firm performance," Journal of Management Accounting Research, Vol. 13, pp.19-45.

[34] Khandwalla. P.N., 1972, "The Effect of Different Types of Competition on the Use of Management Controls", Journal of Accounting Research (Autumn), 275-285.

[35] Kochhar, R. (1997). "Strategic Assets, Capital structure, and Firm Performance." Journal of Financial and Strategic Decisions Volume 10 Number 3 fall 1997.

[36] Kotha, Suresh and Nair, Anil (1995). Strategy and environment as determinant of performance: Evidence from the Japanese machine tool industry, Strategic Management Journal, 16(7): 497-518.

[37] Langfield-Smith, K., 2007, A Review of Quantitative Research in Management Control Systems and Strategy, in: C. S. Chapman, A. G. Hopwood, and M. D. Shields, eds., Handbook of Management Accounting Research, Vol. 1 (Elsevier: Oxford, UK), 753784).

[38] Lawrence, P. \& Lorsch, J. (1967) Organization and Environment: Managing Differentiation and Integration. Harvard University.

[39] Leifer, R., G.C. O'Connor, and M. Rice, 2001, "Implementing Radical Innovation in Mature Firms: The Role of Hubs", Academy of Management Executive 15(3), 102-113.

[40] Link, S. and Naveh, E. (2006). "Standardization and discretion: does the environmental standard ISO 14001 lead to performance benefits?" IEEE Transactions on Engineering Management 53, 508-519.

[41] Magnusson, D., (1981). Toward a Psychology of Situations: an Interactionism Perspective. Lawrence Erlbaum Associates, New Jersey.

[42] Maiga, A.S. and Jacobs, F.A. (2006). Balanced Scorecard, Activity-Based Costing And Company Performance: An Empirical Analysis, Journal of Managerial Issues, 15 (3), p. 283.

[43] Marginson, D. and Ogden, S., (2005). Coping with ambiguity through the budget: the positive effects of budgetary targets on managers' budgeting behaviours. Accounting, Organizations and Society, Volume 30, Issue 5, p. 435-456. Available online at www.sciencedirect.com. Accessed on May 14, 2013

[44] McManus, P. (2012) Measuring urban sustainability: The potential and pitfalls of city rankings. Australian Geographer, 43(4), pp. 411-424.

[45] Merchant, K.A. (1981), "The Design of the Corporate Budgeting System: Influences on Managerial Behavior and Performance”, the Accounting Review, Vol. 56, No. 4, pp. 813829.

[46] Mia, L. and B. Clarke (1999). "Market competition, management accounting systems and business unit performance." Management Accounting Research, vol 10, pp. 137-158.

[47] Miller, K. D. (1993). Industry and country effects on managers' perceptions of environmental uncertainties. Journal of International Business Studies, 24(4): 693-714.

[48] Otley, D. and Wilkinson, C. 1988, 'Organizational behavior: Strategy, structure, environment,

[49] and technology', in Behavioral Accounting Research: A Critical Analysis, ed. K.R. Ferris, Century VII, Columbus, Ohio, pp. 147-170. 
[50] Perren, L. and Grant, P. (2000), "The Evolution of Management Accounting Routines in Small Businesses: A Social Construction Perspective”, Management Accounting Research, 11(4): pp.391-411.

[51] Puranam, P., H. Singh, and M. Zollo, 2006, "Organizing for Innovation: Managing the Coordination-autonomy Dilemma in Technology Acquisitions", Academy of Management Journal 49(2), 263-280.

[52] Reed, R. and R. J. DeFillippi (1990). "Causal ambiguity, barriers to imitation, and sustainable competitive advantage." Academy of Management Review, 15(1), 88-102.

[53] Regan, P. (2012). Making Sense of Uncertainty: An Examination of Environmental Interpretation. International Journal of Business and Management, 7(6),18-29.

[54] Rumelt, R. (1991). "How much does industry matter?" Strategic Management Journal, Vol.12 (3) March, pp167-186.

[55] Şener, R., and Dirlik, S. (2012). Stratejik yönetim kapsaminda stratejik yönetim muhasebesi araçlarının kullanım düzeyi üzerine ampirik bir araştırma (An empirical research on the usage level of strategic administration accounting tools in the scope of strategic management). Proceedings from 31st Turkey Accounting Training Symposium, April 25-29, 2012, Muğla.

[56] Schoute, M. (2009). The realtionship between cost system complexity, purposes of use, and cost system effectiveness, The British Accounting Review, 41, 208-226.

[57] Schulza, D., Wub, A and Chowc, Ch.W.(2010). "Environmental Uncertainty, Comprehensive, Performance Measurement Systems, Performance-Based Compensation, and Organizational Performance." Asia-Pacific Journal of Accounting \& Economics 17 (2010) 17-40.

[58] Tymon Jr. W.G., D. E. Stout, and K.N. Shaw, 1998, "Critical Analysis and Recommendations Regarding the Role of Perceived Environmental Uncertainty in Behavioral Accounting Research", Behavioral Research in Accounting 10, 23-46.

[59] Van der Stede, W. A., Chow, C. W. and Lin, T. W. (2006). Strategy, Choice of Performance Measures, and Performance. Behavioral Research in Accounting . 18, 185205.

[60] Wagner, M. (2005). "How to reconcile environmental and economic performance to improve corporate sustainability: corporate environmental strategies in the European paper industry." Journal of Environmental Management 76, issue no? 105-118.

[61] Wagner, M., Van Phu, N., Azomahou, T. and Wehrmeyer, W. (2002). The relationship between the environmental and economic performance of firms: an empirical analysis of the European paper industry. . Corporate Social Responsibility and Environmental Management 9 (3), 133-146.

[62] Kevin Watson, Beate Klingenberg, Tony Polito, Tom G. Geurts, (2004) "Impact of environmental management system implementation on financial performance: A comparison of two corporate strategies", Management of Environmental Quality: An International Journal, Vol. 15 Iss: 6, pp.622 - 628. 